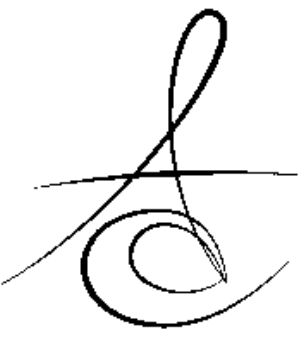

Arş. Gör. Özge YAHYAOĞLU*

Arş. Gör. Görkem YAHYAOĞLU*

\section{6-12 YAŞ GRUBU ÇOCUKLARDA DİŞ HEKİMİNİN DIŞ GÖRÜNÜŞÜNÜN DENTAL DURUM İLE İLIŞ̧KİİNİN DEĞERLENDİRİLMESİ}

\section{EVALUATION OF THE EFFECT OF DENTISTS' APPEARANCE RELATED WITH DENTAL STATUS IN 6-12 YEARS OLD CHILDREN}

Makale Kodu/Article code: 3257

Makale Gönderilme tarihi: 02.01 .2017

Kabul Tarihi: 08.02.2017

\author{
Doç. Dr. Özgül BAYGIN* \\ Doç. Dr. Tamer TÜZÜNER*
}

öz

Amaç: Dental anksiyete; dental tedavi gören hastalarda çok sık karşılaşılan bir durumdur. Anksiyeteye bağlı olarak tedaviden kaçınma, hastanın oral sağlığını etkileyen ciddi problemlere yol açmaktadır. Bu nedenle, dental anksiyetenin erken dönemlerde belirlenmesi, tedavi işlemlerinde hastanın korkusunu yenmesini sağlayarak, tedavi işlemlerinin başarı şansını arttırmaktadır. Çalışmanın amacı çocuklarda dental korku sıkığını, dental korku ile diş çürüğü arasındaki ilişkiyi belirlemek ve dental tedavi sırasında çocuğun endişesini azaltmaya yardımc diş hekimi imajını bulmak ve bu imajın değiştirilerek sağlanılan dental hizmeti geliştirmektir.

Gereç ve Yöntem: Çalışmada, 6-12 yaşları arasındaki toplam 810 hastaya "Çocuk Korku Değerlendirme SkalasıDental Alt Ölçeği (CFSS-DS)" ve "Çocukların Gözüyle Diş Hekimi ve Diş Kliniği Nasıl Olmalı" anketleri uygulandı. Anketler uygulandıktan sonra hastaların ağız-diş muayenesi gerçekleștirilerek DMFT/dmft indeksleri belirlendi.

Bulgular: Çocuk Korku Değerlendirme Skalası- Dental Alt Ölçeği sonuçlarına göre hastalar 3 alt gruba (düşük derece anksiyeteli- orta derece anksiyeteli- yüksek derece anksiyeteli) ayrıldı. Hastaların yaş ve cinsiyete göre anksiyete skorları açısından istatistiksel olarak anlamlı bir fark tespit edildi $(p=0.046, p=0.001)$. Buna göre $6-8$ yaş grubunda ve kızlarda anksiyete skorunun fazla olduğu saptandı. Anksiyete ve diş çürüğü arasındaki ilişki değerlendirildiğinde istatistiksel açıdan anlamlı bir fark tespit edildi (DMFT $p=0.030$, dmft $p=0.015$ ). Buna göre DMFT/dmft değerleri yüksek derece anksiyeteli hastalarda daha fazla bulundu. Diş hekimine gitme yönünden hastaların koruyucu ekipman, maske ve eldiven rengi tercihleri karşılaştırıldığında istatistiksel açıdan anlamlı fark bulunmadı $(p=0.061, p=0.070, p=0.071)$ ve hastaların klinik ve önlük tercihleri karşılaştırıldığında istatistiksel açıdan anlamlı fark bulundu $(p=0.017, p=0.001)$. Buna göre diş hekimine gidenlerin gitmeyenlere göre daha çok düz, sade kliniği ve beyaz önlüğü tercih ettikleri saptandı.

Sonuç: Çocukların hekimin dış görünüşü ile ilgili güçlü bakış açısı ve tercihlere sahip olduğu saptandı. Buna göre anksiyete ile diş çürüğü sıklığı arasında ilișki olabileceği ve hekimin dış görünümünde yapılabilecek küçük değişiklikler ile çocukların anksiyete seviyelerinde azalmaların sağlanabileceği sonucuna varıld.

Anahtar Kelimeler: CFSS-DS, dental anksiyete, dental korku, diş çürügü, hekimin dış görünümü

\section{ABSTRACT}

Aim: Dental anxiety is a common situation encountered for patients receiving dental treatment. Avoidance of dental care due to dental anxiety leads to problems with several adverse consequences to the patients oral health. Therefore, early identification of dental anxiety increases the success of treatment by eliminating the fear of the patient. The aim of this study was to determine the frequency of dental fear and the relationship between dental fear and dental caries, find the ideal dentist appearance that can reduce anxiety of the child and improve dental treatment by altering the dentist appearance.

Materials and Methods: "Children's Fear Survey ScheduleDental Subscale" and "How should be a dentist according to the child?" questionnaires were applied to 810 patients between 6-12 years of age in this study. Patients were examined after the questionnaires and DMFT/dmft indexes were determined.

Results: The patients were divided into three subgroups according to CFSS-DS (low anxiety, medium anxiety, severe anxiety). Statistically significant difference was detected between the anxiety scores according to age and gender of the patients $(p=0.046, p=0.001)$. Accordingly, anxiety score among 6-8 year olds and girls was found to be higher. When the relationship between anxiety and dental caries was evaluated, statistically significant difference was detected. (DMFT $p=0.030, d m f t p=0.015$ ). DMFT/dmft scores were found to be higher in patients with high levels of dental anxiety. No significant differences were found among the colors of equipment, mask and gloves $(p=0.061, p=0.070$, $p=0.071$ ), but there were found the choices of the colors of clinic environment and uniform with regard to dental visits $(p=0.017, p=0.001)$. According to the above findings, patients who visited the dental clinics more frequently have been commonly preferenced smooth, simple clinics and white uniforms rather than the less ones.

Conclusion: Additionally, it was detected that children had a high perception and strong preference towards the apperance of the dentist and dental clinic. It can be concluded that anxiety and dental caries are related and little alterations in the dentists' appearance can reduce the dental anxiety in children.

Keywords: CFSS-DS, dental anxiety, dental fear, dental caries, dentists' appearance

\footnotetext{
* Karadeniz Teknik Üniversitesi Diş Hekimliği Fakültesi Pedodonti Anabilim Dalı, Trabzon.
} 


\section{GİRİş}

Ağız ve diş sağlığı , birey ve toplum sağlığında önemli bir yere sahiptir. İnsan vücudunun gelişmesi ve sağlıklı bir yaşam sürdürmesi için , ağız içindeki dişlerin normal ve sağlıklı olması gerekmektedir ${ }^{1}$. Diş tedavi planlamasının uygulanması ve gerçekleştirilmesinde toplumların diş tedavilerine ve diş hekimlerine karşı duydukları korku ve anksiyetenin önemi büyüktür. Modern teknolojik uygulamalara rağmen diş hekimliği uygulamaları, hala korku ve anksiyete reaksiyonlarının gelişmesindeki etkenlerden birisidir . Dental anksiyetenin sıklıkla anksiyete duyulan obje ve durumlar arasında beşinci sırada yer aldığı bildirilmektedir ${ }^{2}$.

Dental anksiyete, özellikle dış kaynaklı uyarıcı ile ilişkili olmaksızın bireyin her türlü dental işleme karşı hissettiği korku ve endişe olarak tanımlan maktadır. Her yaşta görülmekle birlikte genellikle ço cukluk veya ergenlik döneminde ortaya çıkmaktadır ${ }^{3}$. Çocukluk döneminde görülen dental anksiyete problemi, erişkin dönemde de devam ederek kişilerin, diş tedavilerinden kaçınma ve bunun sonucu olarak da ağız diş sağlığının olumsuz etkilenmesine sebep olabilmektedir $^{1}$. Diş tedavileri sırasında yapılan işlemlerin çocuklar tarafından korkulu bir işlem olarak algılanması, diş hekimliği kliniğinde gerçekleştirilmesi planlanan tedavileri zorlaştırmaktadır. Bu sebeple, dental anksiyetenin diş hekimleri tarafından erken dönemde belirlenerek, tedavi sırasında özel yaklaşım gerektiren çocukların saptanması, diş tedavisinin başarı şansını artırmaktadır ${ }^{4}$.

Dental korkuya sahip hastalar ile korkusu olmayan hasta grupları karşılaştırıldığında , korkulu grupta daha fazla ağız diş sağlığı problemi olduğu bildiril mektedir ${ }^{5,6}$. Peretz ve Mann ${ }^{7}$, dental korkunun, diş hekimlerinin rahat çalışmasını ve diş tedavisini engelle yen önemli bir sorun olduğunu belirtmektedir . Yapılan başka bir çalışmada; okul çağı çocukların \%16'sının diş hekiminden korktuklarını ve buna bağlı olarak da dental tedaviden kaçındıkları rapor edilmektedir ${ }^{8}$. Ayrıca diş hekiminin dış görünümünün dental anksiyete üzerine etkisi olduğu bilinmektedir. Psikologlar, ortamın, fiziksel görünüşün, ilk izlenim ve ikili ilişkiler üzerine etkisinin önemli olduğunu sıklıkla belirtmektedirler. Çocuklar, diş hekimi sözlü iletişime geçmeden önce dış görünümüne dayanarak bir izlenim geliştirmekte ve sıklıkla onların sözlerini, hareketlerini ve mimiklerini kayıt ve analiz etmektedirler. Çocuk, diş hekimi ve dental çevreden memnun olduğu zaman, endişe kaynaklı uyaranlarla baş etmesi o kadar kolaylaşmakta ve böylece çocuğun etkili ve yeterli tedavisi sağlanmaktadır. Bunda da diş hekiminin kendisini sunma şekli çok önemli rol oynamaktadır ${ }^{9}$.

Diş hekimiyle kurulan arkadaşça bir ilişki, hastaların anksiyeteye sebep olduğu bilinen anestezi, aeretör sesi ve görüntüsü gibi spesifik uyaranlarla başa çıkmasına yardımcı olabilmektedir. İlk ziyaretinde çocukla güçlü ve arkadaşça bir ilişki kurmak, çocuğun kendini tehlikede hissetmediği rahat bir atmosfer yaratmaya yardımc olmaktadır. Diş hekimiyle daha pozitif bir ilişkiye sahip olan çocuklarda dental korkunun gelişme olasılığı daha azdır ve randevu sırasında daha az anksiyete göstermektedir. Yetişkinliklerinde de diş hekimini daha fazla ziyaret etmekte ve daha iyi bir ağız hijyenine sahip olmaktadırlar ${ }^{10,11}$. Diş hekimleri hastaların algıları, tercihleri ve korkuları olabileceğinin farkında olmalı ve anksiyetenin azaltılmasına yardımcı olacak iyi kalitede sağlık hizmeti vermelidirler. Bekleme odaları çocuk hastalar ve aileleri için alacakları dental hizmet adına ilk izlenimdir. Bekleme odasının çekiciliği çocukların rahatlamasına ve yapılacak tedaviye karşı pozitif bir tutum sergilemelerine yardımcı olmaktadır ${ }^{12}$.

Bu çalışmada, 6-12 yaş arasındaki çocuklarda dental anksiyete varlığını ve buna bağlı diş çürüklerinin sıklığının belirlenmesi ve ayrıca hekimin dış görünümünün, kullandığı ekipmanların ve çocuğun bulunduğu dental çevrenin anksiyete üzerine etkisinin değerlendirilmesi amaçlanmıştır.

\section{GEREÇ ve YÖNTEM}

Bu çalışma için, Karadeniz Teknik Üniversitesi Tıp Fakültesi Klinik Araştırmalar Etik Kurul Başkanlığından etik kurul onayı alındı (2014/169). Tedavi öncesinde hasta ve ebeveynleri bilgilendirildi ve uygulanacak anketler için ebeveynlerden bilgilendirilmiş onam kağıdı alındı. Çalışma, Karadeniz Teknik Üniversitesi Diş Hekimliği Fakültesi Pedodonti Anabilim Dalı Kliniğine Mayıs 2015-Temmuz 2015 tarihleri arasında başvuran, 6-12 yaşları arasındaki 810 çocuk hastada gerçekleştirildi.

Karadeniz Teknik Üniversitesi Diş Hekimliği Fakültesi Pedodonti Anabilim Dalı Kliniğine 3 ay içinde başvuran, çalışmaya dahil olma kriterlerine uygun toplamda 810 hastaya, kliniğe alınmadan önce bekleme salonunda; 
"Anket 1: Çocuk Korku Değerlendirme SkalasıDental Alt Ölçeği" (CFSS-DS) (13) (Resim 1) uygulandı; Bu skala, çocuklarda dental anksiyete düzeyinin değerlendirilmesinde kullanılan en yaygın skalalardan biridir. Dental tedavinin farklı yönlerini içeren 15 sorudan oluşmaktadır. Çocuklardan her bir soru için 1'den (hiç korkmuyorum) 5'e (aşırı korkuyorum) kadar puan verilmesi istenerek yapıldı ( $1=$ Hiç korkmuyorum, 2= Çok az korkuyorum, 3=Biraz korkuyorum, 4= Çok korkuyorum, 5= Aşırı korkuyorum). Tüm puanlar toplandı. Toplam puan 15-75 arasında skorlanmaktadır. 15-31 puan düşük derecede, 32-38 puan orta derecede, 39 ve üzeri ise yüksek derecede anksiyeteyi gösterecek şekilde değerlendirildi.

"Anket 2: Çocukların Gözüyle Diş Hekimi ve Diş Kliniği Nasıl Olmalı" (Resim 2) uygulandı;

$\mathrm{Bu}$ anket, bir çocuğun gözünden diş hekiminin dış görünümünün ve diş kliniğinin nasıl olması gerektiği ile ilgili sorular içermektedir. Anket 18 sorudan oluşmakta ve içlerinde resimli sorular da bulunmaktadır. Çocukların belirtilen sorulara verdikleri cevaplar değerlendirildi.

Hastalar kliniğe alınarak muayeneleri yapıldıktan sonra daimi dişler için "DMFT" ve süt dişleri için "dmft" indeksi hesaplandı. Yapılan anketlerin sonuçlarına göre 'dental anksiyeteli' bireyler cinsiyet ile "6-8" ve "9-12" yaş gruplarına ayrılarak, hesaplanan DMFT/ dmft skorlarının sonuçları ile beraber, "anksiyete" ve 'diş çürükleri' arasındaki ilişkinin belirlenmesi için gerekli istatistiksel değerlendirmeler yapıldı.

Çalışmada istatistiksel analizler için SPSS (Statistical Package for the Social Sciences, version 13, SPSS Inc, Chicago, Ill, USA) istatistik analiz için kullanıldı. Tanımlayıcı istatistikler için sayı, yüzde, ortalama ve standart sapma hesaplandı. Sürekli değişkenlerin normal dağılıma uygunluğu Kolmogorov-Smirnov testi ile belirlendi. Kategorik değişkenler için "ki kare testi" kullanıldı. Normal dağılım gösteren sürekli değişkenlerin karşılaştırılmasında "Student- $T$ " ve "One way ANOVA", normal dağılım göstermeyen sürekli değişkenlerin karşılaştırılmasında "Mann-Whitney U" ve "Kruskal-Wallis" testleri kullanıldı. Korku ölçeğinden alınan puanlarla ve DMFT skorları arasındaki ilişkiyi incelemek için Spearman korelasyon analizi uygulandı. $p$ değerinin $0.05^{\prime}$ in altında olması istatistiksel anlamlılık olarak kabul edildi.

\section{BULGULAR}

Çalışma, 6-12 yaş arası (yaş ortalaması

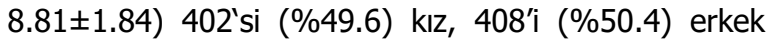
olmak üzere 810 çocuk üzerinde gerçekleştirildi.

CFSS-DS anket sonucuna göre hastaların aldığı skorların, düşük (15-31 puan), orta (32-38 puan) ve yüksek (39-75 puan) derece anksiyete gruplarına göre dağılımı yapıldı. CFSS-DS anket sorularına verilen cevapların ortalama skor değerleri ve standart sapmalarının anksiyete gruplarına, cinsiyete ve yaş aralığına göre dağılımı Tablo 1'de gösterildi. Cinsiyete ve yaş aralığına göre CFSS-DS ortalama skor değerleri karşılaştırıldığında istatistiksel açıdan anlamlı fark bulundu $(p=0.001, p=0.046)$. Buna göre kızların erkeklere göre CFSS-DS ortalama skor değerlerinin daha fazla olduğu ve "6-8" yaş aralığındaki hastaların "9-12" yaş aralığındaki hastalara göre CFSS-DS ortalama skor değerlerinin daha fazla olduğu saptandı.

Çalışmaya dahil edilen hastaların DMFT skorlarının ortalama değeri $1.57 \pm 2.01$ olduğu saptandı. Ortalama değerlerin anksiyete grupları, cinsiyet ve yaş aralığına göre dağılımı Tablo 2'de gösterildi. Cinsiyete göre DMFT ortalama değerleri karşılaştırıldığında istatistiksel açıdan anlamlı fark bulunmadı $(p=0.114)$. Yaş aralığına ve anksiyete gruplarına göre DMFT ortalama değerleri karşılaştırıldığında istatistiksel açıdan anlamlı fark bulundu $(p<0.001, p=0.030)$. Buna göre " $9-12$ " yaş aralığındaki hastaların DMFT ortalama değerlerinin, "6-8" yaş aralığındaki hastalardan daha fazla olduğu tespit edildi. Ayrıca yüksek derece anksiyeteye sahip hastaların DMFT ortalama değerlerinin, orta ve düşük derece anksiyeteye sahip hastalardan fazla olduğu saptandı.

Çalışmaya katılan hastaların dmft skorlarının ortalama değeri $4.64 \pm 3.60$ olduğu saptandı. Ortalama değerlerin anksiyete grupları, cinsiyet ve yaş aralığına göre dağılımı Tablo 3'de gösterildi. Cinsiyete göre dmft ortalama değerleri karşılaştırıldığında istatistiksel açıdan anlamlı fark bulunmadı $(p=0.573)$. Yaş aralığına ve anksiyete gruplarına göre dmft ortalama değerleri karşılaştırıldığında istatistiksel açıdan anlamlı fark bulundu ( $p<0.001, p=0.015)$. Buna göre "6-8" yaş aralığındaki hastaların dmft ortalama değerlerinin, "9-12" yaş aralığındaki hastalara göre daha fazla olduğu tespit edildi. Ayrıca yüksek derece anksiyeteye sahip hastaların dmft ortalama değerlerinin, orta ve düşük derece anksiyeteye sahip hastalardan fazla olduğu saptandı. 


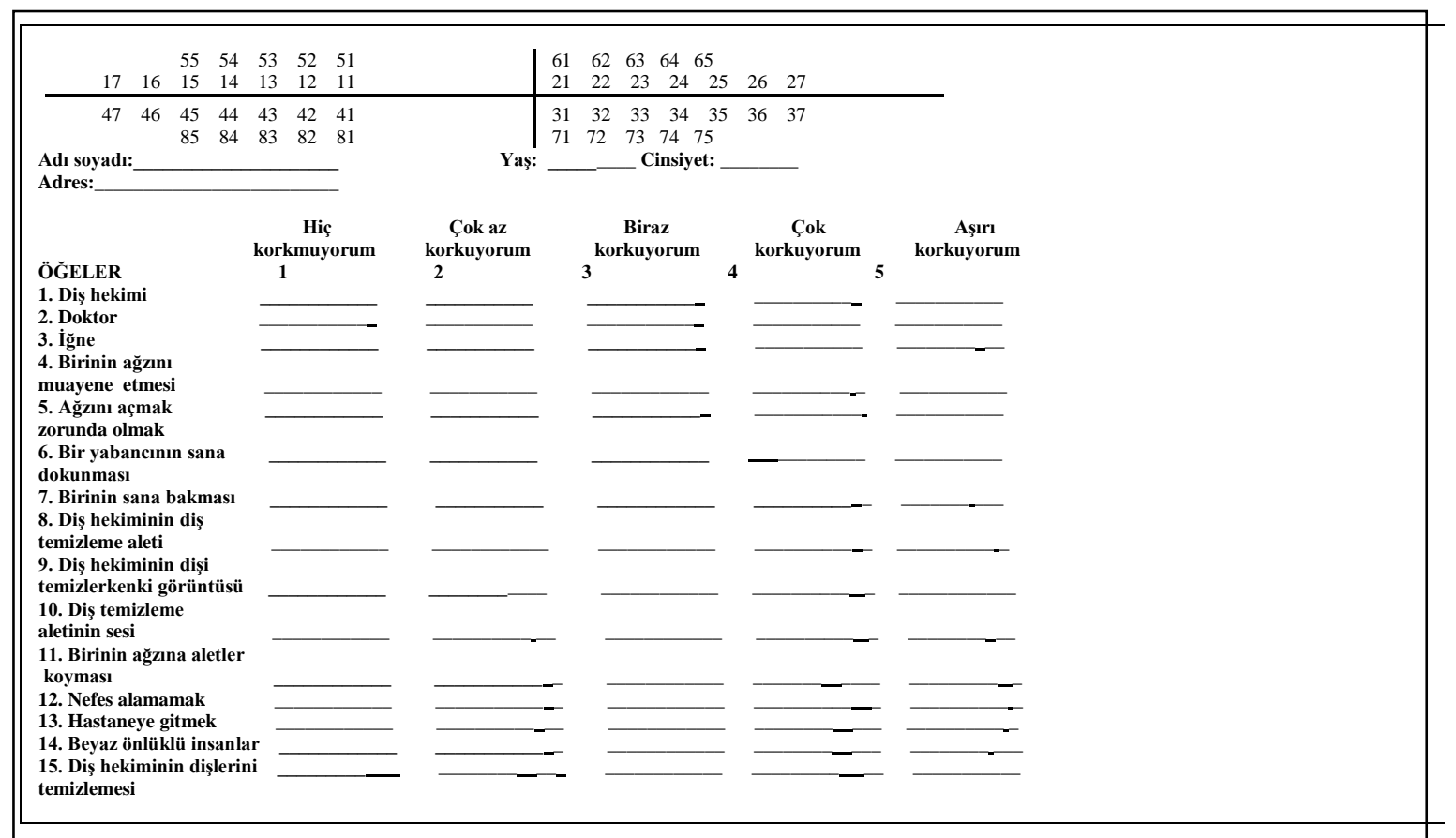

Resim 1. Anket 1- Çocuk Korku Değerlendirme Sklası-Dental Alt Ölçeği (CFSS-D)

1. Daha önce diş hekimine gittin mi? 2. Ailende doktor/diş hekimi var mı?

3. Tedavi esnasında ne hissettin?

4. Kardeşin diş hekimini ziyaret ettiğinde ne hissetmiş?

5. Erkek diş hekimi mi istersin

bayan diş hekimi mi?

6. Hekimin nasıl göründüğü senin için önemli mi?

7. Hangisini kullansın?

8. Hekimin hangi maskeyi kullanmasını tercih edersin?
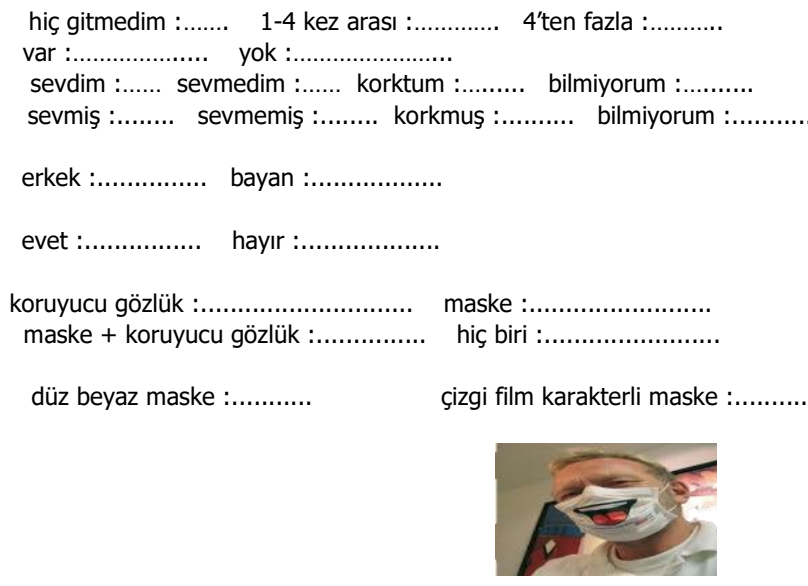

9. Hekimin hangi renk eldiven beyaz renk :........ mavi renk :........ pembe renk :...... yeşil renk :......... giymesini tercih edersin?
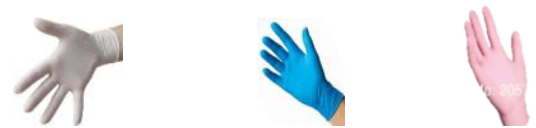

10. Nasıl bir klinikte tedavi olmak istersin? düz klinik :

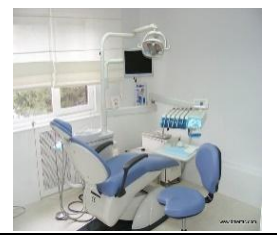

dekore klinik :

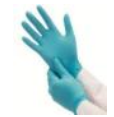

inik :

Resim 2. Anket 2- Çocukların Gözüyle Diş Hekimi ve Diş Kliniği Nasıl Olmalı?

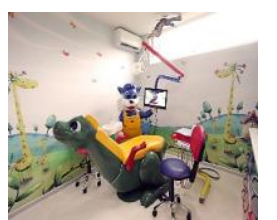
. 


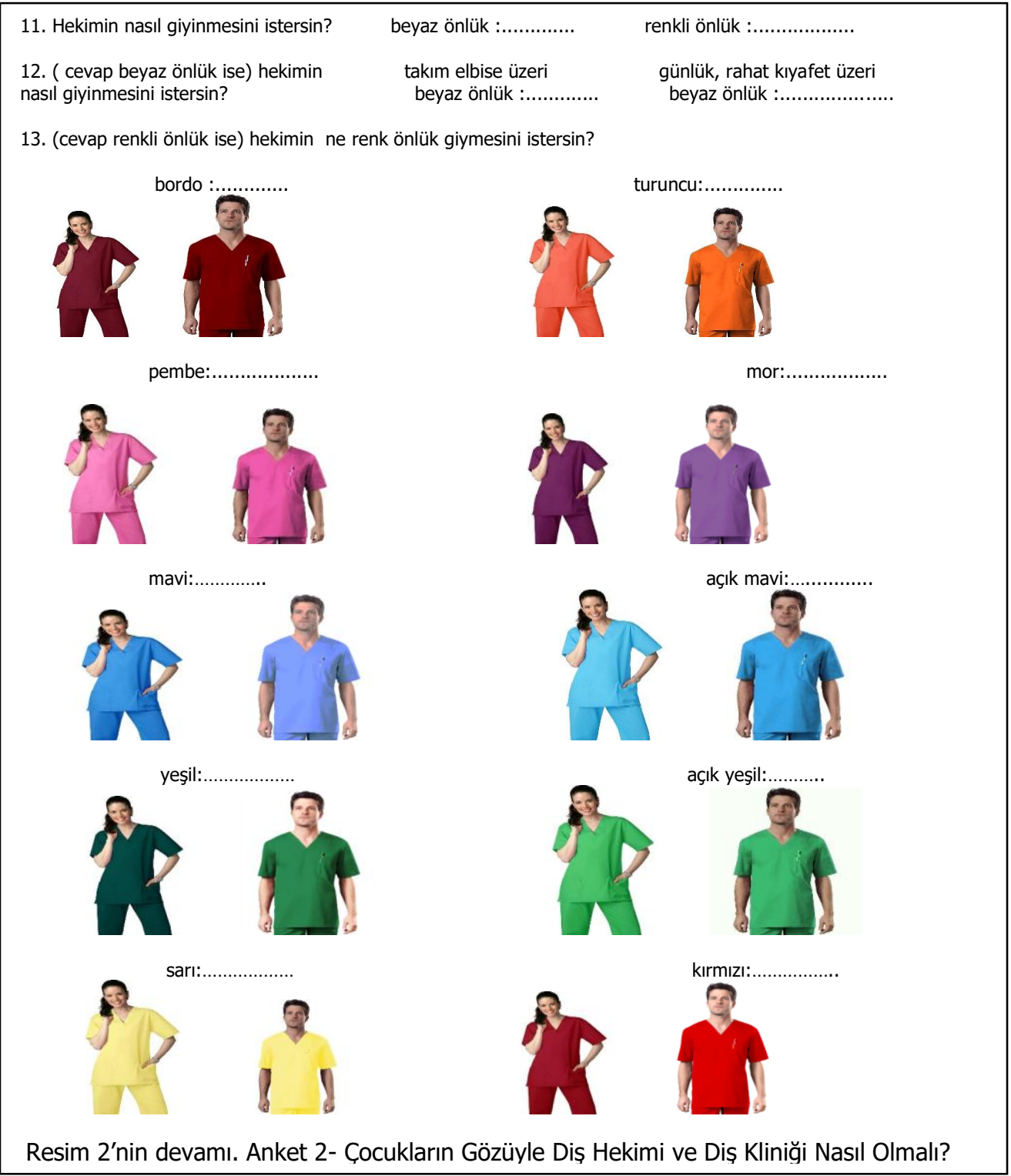

Diş hekimine gitme durumuna göre hastaların koruyucu ekipman, maske, eldiven rengi, klinik ve önlük tercihlerinin dağııımı Tablo 4'de gösterildi. Diş hekimine gitme yönünden hastaların koruyucu ekipman, maske ve eldiven rengi tercihleri karşılaştırıdığında istatistiksel açıdan anlamlı fark bulunmadı $(p=0.061, p=0.070, p=0.071)$. Diş hekimine gitme yönünden hastaların klinik ve önlük tercihleri karşışşıırıdığında istatistiksel açıdan anlamlı fark bulundu ( $p=$ $0.017, p=0.001$ ). Buna göre diş hekimine gidenlerin gitmeyenlere göre daha çok düz, sade kliniği ve beyaz önlüğü tercih ettikleri saptandı. Hekimin renkli önlük giymesini tercih eden 360 hastanın renk tercihlerinin cinsiyete ve yaş aralığına göre dağılımı ise tablo 5'de gösterildi. Cinsiyete göre hastaların renk seçimleri karşılaşııııldığındaistatistiksel açıdan anlamlı fark bulundu $(p<0.001)$. Buna göre kızlar en çok pembe rengi, erkekler en çok açık mavi rengi tercih ettiği bulgulandı. Yaş aralığına göre hastaların renk seçimleri karşılaştııılığında istatistiksel açıdan anlamlı fark bulunmadı $(p=0.130)$.

CFSS skor ortalamalarını etkilediği düşünülen faktörler Tablo 6'da gösterildi. Cinsiyete ve yaş aralığına göre CFSS-DS skor ortalaması karşılaştırıldığında istatistiksel açıdan anlamlı fark bulundu $(p=0.001$, $p=0.046$ ). Buna göre kızların erkeklere göre ve "6-8" yaş aralı̆ı̆ndaki hastaların " $9-12$ " yaş aralı̆ındaki hastalara göre CFSS-DS ortalama skor değerlerinin daha fazla olduğu saptandı. Diş hekimine gidip gitmeme

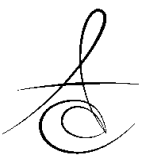


açısından CFSS-DS skor ortalamaları karşılaştırıldığında istatistiksel açıdan anlamlı fark bulundu $(p=0.001)$. Buna göre daha önce diş hekimine gitmemiş hastalarda gidenlere göre daha yüksek CFSS-DS skor ortalaması gözlemlendi. Çalışmaya katılan hastaların diş hekimi tercihlerine göre CFSS-DS skor ortalaması karşılaştırılığında istatistiksel açıdan anlamlı fark bulundu ( $p=0.003)$. Buna göre bayan hekimi tercih eden hastaların CFSS-DS skor ortalamalarının daha fazla olduğu gözlemlendi. Hekimin dış görünümünün önemliliğine göre CFSS-DS skor ortalaması karşılaştırıldığında istatistiksel açıdan anlamlı fark bulunmadı $(p=0.176)$. Koruyucu ekipman tercihlerine göre CFSSDS skor ortalaması karşılaştıııldığında istatistiksel açıdan anlamlı fark bulundu $(p<0.001)$. Buna göre farkın "koruyucu gözlük- hiçbiri", "maske- hiçbiri" ve "koruyucu gözlük+ maske- hiçbiri" den kaynaklandığı saptandı. Tedavi olunan klinik ve hekimin kıyafet tercihlerine göre CFSS-DS skor ortalamaları karşışaşıııldığında istatistiksel açıdan anlamlı fark bulundu $(p<0.001, p=0.021)$. Buna göre dekore klinik ve renkli önlük tercih edenlerin CFSS-DS skor ortalamasının daha yüksek olduğu bulgulandı.

DMFT ortalamalarını etkilediği düşünülen faktörler Tablo 7'de gösterildi. Cinsiyete göre DMFT ortalama skorları karşılaştıııldığında istatistiksel açıdan anlamlı fark bulunmadı $(p=0.114)$. Yaş aralığına ve diş hekimine gidilmesine göre DMFT ortalama skorları karşılaşııııldığında istatistiksel açıdan anlamlı fark bulundu $(p<0.001, p<0.001)$. Buna göre " $9-12$ " yaş aralığındaki hastaların ve daha önce diş hekimine giden hastaların DMFT ortalama skorlarının daha yüksek olduğu bulundu. Hastaların anksiyete gruplarına göre DMFT ortalama skorları karşılaştırıldığında istatistiksel açıdan anlamlı fark bulundu $(p=0.030)$. Buna göre yüksek derece anksiyeteye sahip hastaların, orta ve düşük derece anksiyeteye sahip hastalara göre daha fazla DMFT ortalama skor değerine sahip olduğu saptandı.

DMFT ortalamalarını etkilediği düşünülen faktörler Tablo 8'de gösterildi. Cinsiyete göre dmft ortalama skorları karşılaştıııldığında istatistiksel açıdan anlamlı fark bulunmadı $(p=0.573)$. Yaş aralı̆ına göre dmft ortalama skorları karşılaşııııldığında istatistiksel açıdan anlamlı fark bulundu $(p<0.001)$. Buna göre "68 " yaş aralığındaki hastaların dmft ortalamalarının daha yüksek olduğu saptandı. Diş hekimine gidilmesine göre dmft ortalama skorları karşılaştırıldığında istatistiksel açıdan anlamlı fark bulunmadı $(p=0.929)$. Anksiyete gruplarına göre $\mathrm{dmft}$ skor değerleri karşılaşııııldığında istatistiksel açıdan anlamlı fark bulundu $(p=0.015)$. Buna göre yüksek derece anksiyeteye sahip hastaların, orta ve düşük derece anksiyeteye sahip hastalara göre daha fazla $\mathrm{dmft}$ ortalama skor değerine sahip olduğu tespit edildi.

Tablo 1. CFSS-DS ortalama skor değerlerinin anksiyete grupları, cinsiyet ve yaş aralığına göre dağıımı.

\begin{tabular}{|c|c|c|c|c|c|c|c|c|c|c|c|c|}
\hline \multicolumn{5}{|c|}{ KIZ } & \multicolumn{4}{|c|}{ ERKEK } & \multicolumn{4}{|c|}{ TOPLAM } \\
\hline \multirow{2}{*}{$\begin{array}{l}\text { Yaş } \\
\text { Aralı̆ı̆ }\end{array}$} & Düşük & Orta & Yüksek & Toplam & Düşük & Orta & Yüksek & Toplam & Düşük & Orta & Yüksek & Toplam \\
\hline & $\begin{array}{c}n \\
\text { Ort } \pm S S\end{array}$ & $\begin{array}{c}n \\
\text { Ort } \pm \text { SS }\end{array}$ & $\begin{array}{c}n \\
\text { Ort } \pm \text { SS }\end{array}$ & $\begin{array}{c}n \\
\text { Ort } \pm \text { SS }\end{array}$ & $\begin{array}{c}n \\
\text { Ort } \pm S S \\
\end{array}$ & $\begin{array}{c}n \\
\text { Ort } \pm S S \\
\end{array}$ & $\begin{array}{c}n \\
\text { Ort } \pm S S \\
\end{array}$ & $\begin{array}{c}n \\
\text { Ort } \pm S S\end{array}$ & $\begin{array}{c}n \\
\text { Ort } \pm S S \\
\end{array}$ & $\begin{array}{c}n \\
\text { Ort } \pm S S \\
\end{array}$ & $\begin{array}{c}n \\
\text { Ort } \pm S S \\
\end{array}$ & $\begin{array}{c}n \\
\text { Ort } \pm S S \\
\end{array}$ \\
\hline $6-8$ & $\begin{array}{c}182 \\
23.52 \pm 6.35\end{array}$ & $\begin{array}{c}16 \\
36.38 \pm 0.72\end{array}$ & $\begin{array}{c}11 \\
46.45 \pm 4.59 \\
\end{array}$ & $\begin{array}{c}209 \\
25.71 \pm 8.48\end{array}$ & $\begin{array}{c}160 \\
21.30 \pm 4.36\end{array}$ & $\begin{array}{c}9 \\
34.11 \pm 1.90\end{array}$ & $\begin{array}{c}9 \\
46.44 \pm 7.65 \\
\end{array}$ & $\begin{array}{c}178 \\
23.22 \pm 7.53\end{array}$ & $\begin{array}{c}342 \\
22.48 \pm 5.62\end{array}$ & $\begin{array}{c}25 \\
35.56 \pm 1.66\end{array}$ & $\begin{array}{c}20 \\
46.45 \pm 5.98 \\
\end{array}$ & $\begin{array}{c}387 \\
24.57 \pm 8.14 \\
\end{array}$ \\
\hline $9-12$ & $\begin{array}{c}162 \\
21.35 \pm 4.41 \\
\end{array}$ & $\begin{array}{c}22 \\
33.64 \pm 1.26 \\
\end{array}$ & $\begin{array}{c}9 \\
48.00 \pm 7.09 \\
\end{array}$ & $\begin{array}{c}193 \\
23.99 \pm 7.88 \\
\end{array}$ & $\begin{array}{c}201 \\
20.79 \pm 4.52 \\
\end{array}$ & $\begin{array}{c}16 \\
33.88 \pm 1.75 \\
\end{array}$ & $\begin{array}{c}13 \\
45.23 \pm 5.46 \\
\end{array}$ & $\begin{array}{c}230 \\
23.08 \pm 7.76 \\
\end{array}$ & $\begin{array}{c}363 \\
21.04 \pm 4.48 \\
\end{array}$ & $\begin{array}{c}38 \\
33.74 \pm 1.46 \\
\end{array}$ & $\begin{array}{c}22 \\
46.36 \pm 6.18 \\
\end{array}$ & $\begin{array}{c}423 \\
23.50 \pm 7.82 \\
\end{array}$ \\
\hline $\begin{array}{l}\text { Topla } \\
\text { m }\end{array}$ & $\begin{array}{c}344 \\
22.50 \pm 5.62\end{array}$ & $\begin{array}{c}38 \\
34.79 \pm 1.73\end{array}$ & $\begin{array}{c}20 \\
47.15 \pm 5.73\end{array}$ & $\begin{array}{c}402 \\
24.89 \pm 8.23\end{array}$ & $\begin{array}{c}361 \\
21.01 \pm 4.45\end{array}$ & $\begin{array}{c}25 \\
33.96 \pm 1.77\end{array}$ & $\begin{array}{c}22 \\
45.73 \pm 6.30\end{array}$ & $\begin{array}{c}408 \\
23.14 \pm 7.65\end{array}$ & $\begin{array}{c}705 \\
21.74 \pm 5.11\end{array}$ & $\begin{array}{c}63 \\
34.46 \pm 1.78\end{array}$ & $\begin{array}{c}42 \\
46.40 \pm 6.01\end{array}$ & $\begin{array}{c}810 \\
24.00 \pm 7.99\end{array}$ \\
\hline
\end{tabular}

Tablo 2. DMFT ortalama değerlerinin anksiyete grupları, cinsiyet ve yaş aralığına göre dağıımı.

\begin{tabular}{|c|c|c|c|c|c|c|c|c|c|c|c|c|}
\hline \multicolumn{5}{|c|}{ KIZ } & \multicolumn{4}{|c|}{ ERKEK } & \multicolumn{4}{|c|}{ TOPLAM } \\
\hline \multirow{2}{*}{$\begin{array}{l}\text { Yaş } \\
\text { Aralığı }\end{array}$} & Düşük & Orta & Yüksek & Toplam & Düşük & Orta & Yüksek & Toplam & Düşük & Orta & Yüksek & Toplam \\
\hline & $\begin{array}{c}n \\
\text { DMFT }\end{array}$ & $\begin{array}{c}n \\
\text { DMFT }\end{array}$ & $\begin{array}{c}n \\
\text { DMFT }\end{array}$ & $\begin{array}{c}n \\
\text { DMFT }\end{array}$ & $\begin{array}{c}\mathrm{n} \\
\text { DMFT }\end{array}$ & $\begin{array}{c}\mathrm{n} \\
\mathrm{DMFT}\end{array}$ & $\begin{array}{c}n \\
\text { DMFT }\end{array}$ & $\begin{array}{c}\mathrm{n} \\
\text { DMFT }\end{array}$ & $\begin{array}{c}n \\
\text { DMFT }\end{array}$ & $\begin{array}{c}n \\
\text { DMFT }\end{array}$ & $\begin{array}{c}n \\
\text { DMFT }\end{array}$ & $\begin{array}{c}n \\
\text { DMFT }\end{array}$ \\
\hline $6-8$ & $\begin{array}{c}182 \\
0.59 \pm 1.17\end{array}$ & $\begin{array}{c}16 \\
0.44 \pm 1.09\end{array}$ & $\begin{array}{c}11 \\
1.27 \pm 0.79\end{array}$ & $\begin{array}{c}209 \\
0.61 \pm 1.56\end{array}$ & $\begin{array}{c}160 \\
0.66 \pm 1.21\end{array}$ & $\begin{array}{c}9 \\
0.56 \pm 1.33\end{array}$ & $\begin{array}{c}9 \\
1.44 \pm 1.01\end{array}$ & $\begin{array}{c}178 \\
0.70 \pm 1.22\end{array}$ & $\begin{array}{c}342 \\
0.62 \pm 1.19\end{array}$ & $\begin{array}{c}25 \\
0.48 \pm 1.16\end{array}$ & $\begin{array}{c}20 \\
1.35 \pm 0.88\end{array}$ & $\begin{array}{c}387 \\
0.65 \pm 1.18\end{array}$ \\
\hline $9-12$ & $\begin{array}{c}162 \\
2.42 \pm 2.37\end{array}$ & $\begin{array}{c}22 \\
2.59 \pm 2.30\end{array}$ & $\begin{array}{c}9 \\
2.22 \pm 1.09\end{array}$ & $\begin{array}{c}193 \\
2.43 \pm 2.31\end{array}$ & $\begin{array}{c}201 \\
2.44 \pm 2.24\end{array}$ & $\begin{array}{c}16 \\
1.94 \pm 1.91\end{array}$ & $\begin{array}{c}13 \\
2.15 \pm 1.07\end{array}$ & $\begin{array}{c}230 \\
2.39 \pm 2.17\end{array}$ & $\begin{array}{c}363 \\
2.43 \pm 2.29\end{array}$ & $\begin{array}{c}38 \\
2.32 \pm 2.14\end{array}$ & $\begin{array}{c}22 \\
2.18 \pm 1.05\end{array}$ & $\begin{array}{c}423 \\
2.41 \pm 2.23 \\
\end{array}$ \\
\hline Toplam & $\begin{array}{c}344 \\
1.45 \pm 2.05\end{array}$ & $\begin{array}{c}38 \\
1.68 \pm 2.16\end{array}$ & $\begin{array}{c}20 \\
1.70 \pm 1.03\end{array}$ & $\begin{array}{c}402 \\
1.49 \pm 2.02\end{array}$ & $\begin{array}{c}361 \\
1.65 \pm 2.05\end{array}$ & $\begin{array}{c}25 \\
1.44 \pm 1.83\end{array}$ & $\begin{array}{c}22 \\
1.86 \pm 1.08\end{array}$ & $\begin{array}{c}408 \\
1.65 \pm 2.00\end{array}$ & $\begin{array}{c}705 \\
1.55 \pm 2.05\end{array}$ & $\begin{array}{c}63 \\
1.59 \pm 2.02\end{array}$ & $\begin{array}{c}42 \\
1.79 \pm 1.05\end{array}$ & $\begin{array}{c}810 \\
1.57 \pm 2.01\end{array}$ \\
\hline
\end{tabular}


Atatürk Üniv. Diş Hek. Fak. Derg.

YAHYAOGLU, BAYGIN

] Dent Fac Atatürk Uni

Cilt:28, Sayı:3, Yıl: 2018, Sayfa, 292-304

Tablo 3. dmft ortalama değerlerinin anksiyete grupları, cinsiyet ve yaş aralığına göre dağılımı.

\begin{tabular}{|c|c|c|c|c|c|c|c|c|c|c|c|c|}
\hline \multicolumn{5}{|c|}{ KIZ } & \multicolumn{4}{|c|}{ ERKEK } & \multicolumn{4}{|c|}{ TOPLAM } \\
\hline Yaş & Düşük & Orta & Yüksek & Toplam & Düşük & Orta & Yüksek & Toplam & Düşük & Orta & Yüksek & Toplam \\
\hline Aralığı & $\begin{array}{c}n \\
\mathrm{dmft}\end{array}$ & $\begin{array}{c}\mathrm{n} \\
\mathrm{dmft}\end{array}$ & $\begin{array}{c}\mathrm{n} \\
\mathrm{dmft}\end{array}$ & $\begin{array}{c}\mathrm{n} \\
\mathrm{dmft}\end{array}$ & $\begin{array}{c}n \\
\mathrm{dmft}\end{array}$ & $\begin{array}{c}\mathrm{n} \\
\mathrm{dmft}\end{array}$ & $\begin{array}{c}\mathrm{n} \\
\mathrm{dmft}\end{array}$ & $\begin{array}{c}\mathrm{n} \\
\mathrm{dmft}\end{array}$ & $\begin{array}{c}\mathrm{n} \\
\mathrm{dmft}\end{array}$ & $\begin{array}{c}\mathrm{n} \\
\mathrm{dmft}\end{array}$ & $\begin{array}{c}\mathrm{n} \\
\mathrm{dmft}\end{array}$ & $\begin{array}{c}\mathrm{n} \\
\mathrm{dmft}\end{array}$ \\
\hline $6-8$ & $\begin{array}{c}182 \\
6.46 \pm 3.87\end{array}$ & $\begin{array}{c}16 \\
6.31 \pm 2.68\end{array}$ & $\begin{array}{c}11 \\
7.91 \pm 3.18\end{array}$ & $\begin{array}{c}209 \\
6.53 \pm 3.76\end{array}$ & $\begin{array}{c}160 \\
6.01 \pm 3.01\end{array}$ & $\begin{array}{c}9 \\
5.11 \pm 2.15\end{array}$ & $\begin{array}{c}9 \\
6.33 \pm 3.20\end{array}$ & $\begin{array}{c}178 \\
5.98 \pm 2.97\end{array}$ & $\begin{array}{c}342 \\
6.25 \pm 3.50\end{array}$ & $\begin{array}{c}25 \\
5.88 \pm 2.52\end{array}$ & $\begin{array}{c}20 \\
7.20 \pm 3.21\end{array}$ & $\begin{array}{c}387 \\
6.27 \pm 3.43\end{array}$ \\
\hline $9-12$ & $\begin{array}{c}162 \\
2.88 \pm 3.02\end{array}$ & $\begin{array}{c}22 \\
2.32 \pm 3.06\end{array}$ & $\begin{array}{c}9 \\
5.44 \pm 3.00\end{array}$ & $\begin{array}{c}193 \\
2.93 \pm 3.06\end{array}$ & $\begin{array}{c}201 \\
3.26 \pm 3.08\end{array}$ & $\begin{array}{c}16 \\
3.50 \pm 2.68\end{array}$ & $\begin{array}{c}13 \\
4.31 \pm 3.15\end{array}$ & $\begin{array}{c}230 \\
3.33 \pm 3.06\end{array}$ & $\begin{array}{c}363 \\
3.09 \pm 3.06\end{array}$ & $\begin{array}{c}38 \\
2.82 \pm 2.93\end{array}$ & $\begin{array}{c}22 \\
4.77 \pm 3.07\end{array}$ & $\begin{array}{c}423 \\
3.15 \pm 3.07\end{array}$ \\
\hline Toplam & $\begin{array}{c}344 \\
4.77 \pm 3.93\end{array}$ & $\begin{array}{c}38 \\
4.00 \pm 3.50\end{array}$ & $\begin{array}{c}20 \\
6.80 \pm 3.27\end{array}$ & $\begin{array}{c}402 \\
4.80 \pm 3.88\end{array}$ & $\begin{array}{c}361 \\
4.48 \pm 3.34\end{array}$ & $\begin{array}{c}25 \\
4.08 \pm 2.58\end{array}$ & $\begin{array}{c}22 \\
5.14 \pm 3.26\end{array}$ & $\begin{array}{c}408 \\
4.49 \pm 3.29\end{array}$ & $\begin{array}{c}705 \\
4.62 \pm 3.64\end{array}$ & $\begin{array}{c}63 \\
4.03 \pm 3.14\end{array}$ & $\begin{array}{c}42 \\
5.93 \pm 3.33\end{array}$ & $\begin{array}{c}810 \\
4.64 \pm 3.60\end{array}$ \\
\hline
\end{tabular}

Tablo 4. Diş hekimine gitme durumuna göre hastaların koruyucu ekipman, maske, eldiven rengi, klinik ve önlük tercihlerinin dağılımı.

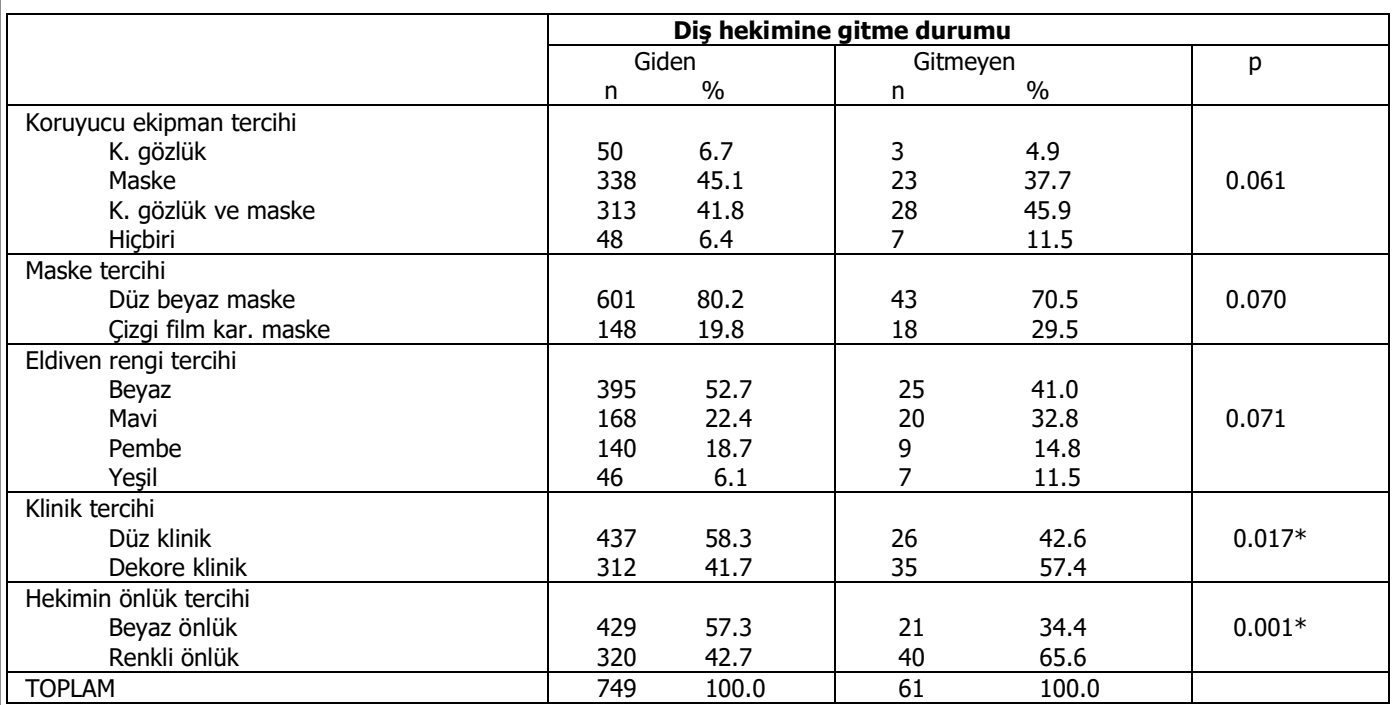

Tablo 5. Hastaların önlük rengi tercihlerinin cinsiyet ve yaşa göre dağııımı.

\begin{tabular}{|c|c|c|c|c|c|c|c|c|c|c|c|c|c|c|c|c|c|c|c|c|c|c|c|}
\hline & \multicolumn{23}{|c|}{ Hastaların önlük rengi tercihleri } \\
\hline & \multicolumn{2}{|c|}{ Bordo } & \multicolumn{2}{|c|}{ Turuncu } & \multirow{2}{*}{\multicolumn{2}{|c|}{$\begin{array}{l}\text { Pembe } \\
\text { n \% }\end{array}$}} & \multicolumn{2}{|c|}{ Mor } & \multicolumn{2}{|c|}{ Mavi } & \multicolumn{2}{|c|}{$\begin{array}{l}\text { Açık } \\
\text { Mavi }\end{array}$} & \multicolumn{2}{|c|}{ Yeşil } & \multicolumn{2}{|c|}{$\begin{array}{l}\text { Açık } \\
\text { Yeşil }\end{array}$} & \multicolumn{2}{|c|}{ Sarı } & \multicolumn{2}{|c|}{ Kırmızı } & \multicolumn{2}{|c|}{ Toplam } & \multirow[t]{2}{*}{$\mathbf{p}$} \\
\hline & $n$ & $\%$ & $n$ & $\%$ & & & & & $\mathbf{n}$ & $\%$ & $n$ & $\%$ & & $\%$ & $\mathbf{n}$ & & $n$ & $\%$ & $n^{c}$ & $\%$ & & $\%$ & \\
\hline $\begin{array}{l}\text { Cinsiyet } \\
\text { Kız } \\
\text { Erkek } \\
\text { Toplam } \\
\end{array}$ & $\begin{array}{l}13 \\
23 \\
36 \\
\end{array}$ & $\begin{array}{l}6.1 \\
15.8 \\
10.0 \\
\end{array}$ & \begin{tabular}{|l|}
8 \\
12 \\
20 \\
\end{tabular} & $\begin{array}{l}3.7 \\
8.2 \\
5.6 \\
\end{array}$ & \begin{tabular}{|ll}
98 & 4 \\
4 & 2 \\
102 & \\
\end{tabular} & $\begin{array}{l}5.8 \\
.7 \\
28.3 \\
\end{array}$ & \begin{tabular}{|l}
19 \\
3 \\
22 \\
\end{tabular} & $\begin{array}{l}8 . \\
2 . \\
6 .\end{array}$ & $\begin{array}{l}13 \\
26 \\
39\end{array}$ & $\begin{array}{l}6.1 \\
17.8 \\
10.85\end{array}$ & $\begin{array}{l}16 \\
38 \\
54 \\
\end{array}$ & $\begin{array}{l}7.5 \\
26.0 \\
15.0 \\
\end{array}$ & $\begin{array}{l}1 \\
6 \\
7 \\
\end{array}$ & $\begin{array}{l}0.5 \\
4.1 \\
1.9 \\
\end{array}$ & \begin{tabular}{|l}
14 \\
10 \\
24 \\
\end{tabular} & $\begin{array}{l}6.5 \\
6.8 \\
6.7 \\
\end{array}$ & \begin{tabular}{|l|}
11 \\
8 \\
19 \\
\end{tabular} & $\begin{array}{l}5.1 \\
5.5 \\
5.3 \\
\end{array}$ & $\begin{array}{l}21 \\
16 \\
37 \\
\end{array}$ & $\begin{array}{l}9.8 \\
11.0 \\
10.3 \\
\end{array}$ & $\begin{array}{l}214 \\
146 \\
360\end{array}$ & $\begin{array}{l}100.0 \\
100.0 \\
100.0\end{array}$ & $\begin{array}{l}<0.001 \\
*\end{array}$ \\
\hline $\begin{array}{c}\text { Yaş aralığı } \\
6-8 \\
9-12 \\
\text { Toplam }\end{array}$ & $\begin{array}{l}16 \\
20 \\
36\end{array}$ & $\begin{array}{l}9.0 \\
10.9 \\
10.0\end{array}$ & $\begin{array}{l}11 \\
9 \\
20\end{array}$ & $\begin{array}{l}6.2 \\
4.9 \\
5.6\end{array}$ & \begin{tabular}{|l}
58 \\
44 \\
102
\end{tabular} & $\begin{array}{l}32.8 \\
24.0 \\
28.3\end{array}$ & $\begin{array}{l}13 \\
9 \\
22\end{array}$ & $\begin{array}{l}7.3 \\
4 . \\
6 .\end{array}$ & $\begin{array}{l}17 \\
22 \\
39\end{array}$ & $\begin{array}{l}9.6 \\
12.0 \\
10.8\end{array}$ & $\begin{array}{l}21 \\
33 \\
54\end{array}$ & $\begin{array}{l}11.9 \\
18.0 \\
15.0\end{array}$ & $\begin{array}{l}3 \\
4 \\
7\end{array}$ & $\begin{array}{l}3.4 \\
2.2 \\
1.9\end{array}$ & $\begin{array}{l}6 \\
18 \\
24\end{array}$ & $\begin{array}{l}3.4 \\
9.8 \\
6.7\end{array}$ & $\begin{array}{l}11 \\
8 \\
19\end{array}$ & $\begin{array}{l}6.2 \\
4.4 \\
5.3\end{array}$ & $\begin{array}{l}21 \\
16 \\
37\end{array}$ & $\begin{array}{l}11.9 \\
8.7 \\
10.3\end{array}$ & $\begin{array}{l}177 \\
183 \\
360\end{array}$ & $\begin{array}{l}100.0 \\
100.0 \\
100.0\end{array}$ & 0.130 \\
\hline
\end{tabular}


Tablo 6. CFSS-DS skorunu etkileyebilecek faktörler.

\begin{tabular}{|c|c|c|c|}
\hline Etkileyebilecek faktörler & \multicolumn{3}{|c|}{ CFSS-DS Skoru } \\
\hline $\begin{array}{l}\text { Erkek } \\
\text { Kız } \\
\text { Toplam }\end{array}$ & $\begin{array}{l}23.14 \pm 7.65 \\
24.89 \pm 8.23 \\
24.00 \pm 7.99\end{array}$ & $\begin{array}{l}21 \\
23 \\
22\end{array}$ & $0.001^{*}$ \\
\hline $\begin{array}{ll}6-8 \\
\\
9-12 \\
\text { Toplam } \\
\end{array}$ & $\begin{array}{l}24.57 \pm 8.14 \\
23.50 \pm 7.82 \\
24.00 \pm 7.99\end{array}$ & $\begin{array}{l}22 \\
21 \\
22\end{array}$ & $0.046^{*}$ \\
\hline $\begin{array}{l}\text { Diş hekimine gitme } \\
\text { durumu } \\
\text { Gitmiş } \\
\text { Gitmemiş } \\
\end{array}$ & $\begin{array}{l}23.79 \pm 7.97 \\
26.70 \pm 7.57\end{array}$ & $\begin{array}{l}21 \\
26\end{array}$ & $0.001^{*}$ \\
\hline $\begin{array}{c}\text { Tedavi esnasındaki hissi } \\
\text { Sevdim } \\
\text { Sevmedim } \\
\text { Korktum } \\
\text { Bilmiyorum } \\
\end{array}$ & $\begin{array}{l}20.96 \pm 5.78 \\
25.34 \pm 9.08 \\
28.97 \pm 9.06 \\
25.76 \pm 7.56 \\
\end{array}$ & $\begin{array}{c}19 \\
22.5 \\
28 \\
25\end{array}$ & $<0.001^{*}$ \\
\hline $\begin{array}{l}\text { Diş hekimi tercihi } \\
\text { Bayan } \\
\text { Erkek } \\
\text { Fark etmez } \\
\end{array}$ & $\begin{array}{l}24.66 \pm 8.17 \\
22.78 \pm 7.55 \\
23.45 \pm 7.56\end{array}$ & $\begin{array}{l}22 \\
21 \\
21\end{array}$ & $0.003^{*}$ \\
\hline $\begin{array}{l}\text { Hekimin dış } \\
\text { görünümünün önemi } \\
\text { Evet } \\
\text { Hayır } \\
\text { Fark etmez } \\
\end{array}$ & $\begin{array}{l}23.87 \pm 8.56 \\
24.14 \pm 7.71 \\
22.06 \pm 7.61\end{array}$ & $\begin{array}{l}21 \\
22 \\
20\end{array}$ & 0.176 \\
\hline $\begin{array}{l}\text { Koruyucu ekipman } \\
\text { Koruyucu gözlük } \\
\text { Maske } \\
\text { Koruyucu gözlük+ maske } \\
\text { Hiçbiri }\end{array}$ & $\begin{array}{r}24.57 \pm 7.95 \\
23.56 \pm 7.62 \\
23.45 \pm 7.53 \\
29.87 \pm 10.61 \\
\end{array}$ & $\begin{array}{l}22 \\
21 \\
21 \\
27\end{array}$ & $<0.001^{*}$ \\
\hline $\begin{array}{l}\text { Tedavi olunan klinik } \\
\text { özelliği } \\
\text { Düz klinik } \\
\text { Dekore klinik } \\
\end{array}$ & $\begin{array}{l}23.29 \pm 7.95 \\
24.96 \pm 7.95\end{array}$ & $\begin{array}{l}21 \\
23\end{array}$ & $<0.001^{*}$ \\
\hline $\begin{array}{c}\text { Hekimin önlük tercihi } \\
\text { Beyaz önlük } \\
\text { Renkli önlük } \\
\end{array}$ & $\begin{array}{l}23.43 \pm 7.61 \\
24.73 \pm 8.39\end{array}$ & $\begin{array}{c}21 \\
22.5\end{array}$ & $0.021 *$ \\
\hline
\end{tabular}

Tablo 7. DMFT ortalama skorunu etkileyebilecek faktörler.

\begin{tabular}{|c|c|c|c|}
\hline $\begin{array}{l}\text { Etkileyebilecek } \\
\text { faktörler }\end{array}$ & $\begin{array}{c}\text { Ort } \\
\text { Median }\end{array}$ & $\begin{array}{r}\text { DN } \\
\pm \\
\text { p }\end{array}$ & SS \\
\hline $\begin{array}{l}\text { Cinsiyet } \\
\text { Erkek } \\
\text { Kız } \\
\text { Toplam } \\
\end{array}$ & $\begin{array}{l}1.65 \pm 2.00 \\
1.49 \pm 2.02 \\
1.57 \pm 2.01 \\
\end{array}$ & $\begin{array}{l}1 \\
1 \\
1\end{array}$ & 0.114 \\
\hline $\begin{array}{ll}6-8 \\
9-12 \\
\text { Toplam } \\
\end{array}$ & $\begin{array}{l}0.65 \pm 1.18 \\
2.41 \pm 2.23 \\
1.57 \pm 2.01 \\
\end{array}$ & $\begin{array}{l}0 \\
2 \\
1 \\
\end{array}$ & $<0.001^{*}$ \\
\hline $\begin{array}{l}\text { Diş hekimine gitme } \\
\text { durumu } \\
\\
\text { Gitmiş } \\
\text { Gitmemiş }\end{array}$ & $\begin{array}{l}1.65 \pm 2.04 \\
0.58 \pm 1.18\end{array}$ & $\begin{array}{l}1 \\
0\end{array}$ & $<0.001^{*}$ \\
\hline 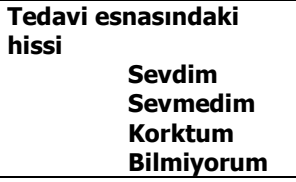 & $\begin{array}{l}1.60 \pm 1.97 \\
2.32 \pm 2.82 \\
1.58 \pm 1.78 \\
1.06 \pm 1.75\end{array}$ & $\begin{array}{l}1 \\
1 \\
1 \\
0\end{array}$ & $<0.001^{*}$ \\
\hline $\begin{array}{c}\text { Anksiyete skor grupları } \\
\text { Düşük } \\
\text { Orta } \\
\text { Yüksek } \\
\text { Toplam } \\
\end{array}$ & $\begin{array}{l}1.55 \pm 2.05 \\
1.59 \pm 2.02 \\
1.79 \pm 1.05 \\
1.57 \pm 2.01 \\
\end{array}$ & $\begin{array}{l}1 \\
1 \\
1 \\
1\end{array}$ & $0.030 *$ \\
\hline
\end{tabular}

Tablo 8. dmft ortalama skorunu etkileyebilecek faktörler.

\begin{tabular}{|c|c|c|c|}
\hline Etkileyebilecek faktörler & \multicolumn{3}{|c|}{ dmft } \\
\hline $\begin{array}{ll}\text { Cinsiyet } & \\
& \text { Erkek } \\
& \text { Kız } \\
& \text { Toplam } \\
\end{array}$ & $\begin{array}{l}4.49 \pm 3.29 \\
4.80 \pm 3.88 \\
4.64 \pm 3.60 \\
\end{array}$ & $\begin{array}{l}4 \\
4 \\
4 \\
\end{array}$ & 0.573 \\
\hline 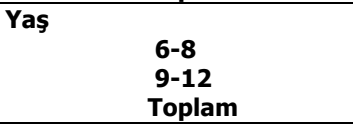 & $\begin{array}{l}6.27 \pm 3.43 \\
3.15 \pm 3.07 \\
4.64 \pm 3.60 \\
\end{array}$ & $\begin{array}{l}6 \\
3 \\
4 \\
\end{array}$ & $<0.001^{*}$ \\
\hline $\begin{array}{l}\text { Diş hekimine gitme durumu } \\
\text { Gitmiş } \\
\text { Gitmemiş }\end{array}$ & $\begin{array}{l}4.64 \pm 3.60 \\
4.69 \pm 3.63\end{array}$ & $\begin{array}{l}4 \\
4\end{array}$ & 0.929 \\
\hline $\begin{array}{l}\text { Tedavi esnasındaki hissi } \\
\text { Sevdim } \\
\text { Sevmedim } \\
\text { Korktum } \\
\text { Bilmiyorum }\end{array}$ & $\begin{array}{l}4.85 \pm 3.59 \\
4.01 \pm 3.64 \\
4.36 \pm 3.46 \\
4.74 \pm 3.74\end{array}$ & $\begin{array}{c}5 \\
3.5 \\
4 \\
4\end{array}$ & 0.171 \\
\hline $\begin{array}{l}\text { Anksiyete skor grupları } \\
\text { Düşük } \\
\text { Orta } \\
\text { Yüksek } \\
\text { Toplam }\end{array}$ & $\begin{array}{l}4.62 \pm 3.64 \\
4.03 \pm 3.14 \\
5.93 \pm 3.33 \\
4.64 \pm 3.60 \\
\end{array}$ & $\begin{array}{l}4 \\
4 \\
6 \\
4\end{array}$ & $0.015^{*}$ \\
\hline
\end{tabular}

\section{TARTIŞMA}

Dental anksiyete; diş tedavisi gören hastalarda çok sık karşılaşlan, hekim ve hasta yönünden sorun oluşturabilen bir durumdur ${ }^{14}$. Çocuklarda diş tedavisi korkusu, ciddi sağlık problemlerinin kaynağı olarak görülmektedir. Ayrıca bu durum diş tedavisi sırasında rahatsız edici davranış, tedaviden kaçınma olarak devam edebilir ve ağız sağlığında şiddetli yan etkilere sebep olabilir. Bu tür davranışı önleyebilmek için endişeli çocuğu mümkün olan en erken yaşta belirleyebilmek önemlidir ${ }^{15}$.

Dental anksiyetenin subjektif bir konu olması ve her bireyde değişik derecelerde olması sebebiyle ölçümü zor bir işlemdir . Diş hekimlerinin, hastalarda mevcut olabilen dental anksiyete düzeylerini etkin olarak değerlendirebilmele ri, hastaların tedavi gereksinimlerinin ve planlamalarının yapılmasında kolaylık sağlamasının yanı sıra , klinik zaman kaybını önlemektedir. Bu amaçla dental korku ve anksiyeteyi değerlendirmede çeşitli yöntemler geliştirilmiştir ${ }^{16}$. Çocuk Korku Değerlendirme Skalası Dental Alt Ölçeği (CFSS-DS) 1982 yılında geliştirilen, çocuklarda dental korkuyu ölçmede kullanılan ve iyi bilinen bir psikometrik skaladır. Bu çalışmanın amaçlarından biri dental anksiyete ve korkuyu CFSS-DS kullanarak değerlendirmek ve ayrıca dental anksiyete ile çürüğün ilişkisini belirleyebilmektir. 
Literatürde dental anksiyetenin CFSS-DS skalası ile değerlendirildiği çalışmalar mevcuttur ${ }^{17-20}$. Bu çalışmalara benzer şekilde sunulan çalışmada da CFSSDS skorları değerlendirilirken 2 adet sınır (cut-off) puan belirlenmiştir. CFSS-DS skoru 39 ve 39'dan fazla olanlar yüksek dereceli anksiyeteli bulunurken, 32 ve 39 puan arasında olanlar orta dereceli anksiyeteli bulunmuş ve dental korku için sınır bir alan belirlenmiştir. Çalışmaya dahil olan hastaların \%5.2'si yüksek derece anksiyeteli, \%7.8'si ise orta derece anksiyeteli bulunmuştur. Bu çocukların belirli derecede dental korkusu vardır ve yüksek derecede dental korku ya da fobi geliştirme riskine sahiptirler. Bu çocuklara ekstra ilgi ve önem gösterilirse dental korku ve fobi gelişimi önlenebilir ${ }^{21,22}$. Ancak Yamada ve arkadaşları ${ }^{23}$ yaptıkları çalışmada düşük anksiyeteye sahip bir çok olumsuz davranış gösteren çocuk hasta olabileceği gibi yüksek anksiyeteye sahip olup da olumlu davranış gösteren çocukların da olabileceğine dikkat çekmişlerdir.

Dental anksiyetenin yaşla ilgisini araştırdığımızda günümüze kadar yapılan çalışmalarda , çoğunlukla dental anksiyete ile yaş arasında negatif yönde bir korelasyon olduğu bildirilmiştir . Folayan ve arkadaşları $^{24}$ ve Cuthbert ve Malamed ${ }^{13}$, dental anksiyete seviyesinin 6-7 yaş civarında azalmaya başladığını ve yaş ilerledikçe dental uygulamalarla baş etme yeteneğinin daha da arttığını bildirmektedirler . Le Baron ve Zeltzer'e ${ }^{25}$ göre, çocuklar yaşları büyüdükçe korkularını kontrol etmeyi öğrenebilirler. Türk çocukları ile yapılan bir çalışmada 3-6 yaş grubu çocukların \%30'unun, 7-12 yaş grubu çocukların \%11'inin dental anksiyeteli oldukları belirlenmiştir ${ }^{4}$. Sunulan çalışmada ise bu çalışmalara benzer şekilde yaş ile dental anksiyete arasında negatif yönde bir korelasyon olduğu gözlemlenmiş ve istatistiksel açıdan anlamlı bir fark saptanmıştır $(p=0.046)$.

Dental anksiyeteyi belirleyici faktörlerin bir diğerinin de cinsiyet farkı olduğu bildirilmektedir. Cinsiyetin dental anksiyete gelişiminde doğal bir etiyoloji olduğunu açıklayan Corah'ın ${ }^{26}$ yanısıra yapılan araştırmalarda genellikle kızların dental anksiyete seviyesinin erkeklerden daha yüksek olduğu bildirilmiştir $\quad 7,18,27$. Liddell ve Murray ${ }^{28}$ de 9 yaşından sonra cinsiyet farkIılığının ortaya çıkmaya başladığını ve kızlarda dental anksiyetenin daha yüksek olduğunu belirtmişlerdir. Bodrumlu ve arkadaşlarının ${ }^{5}$ yaptığı çalışmada ise erkeklerde dental anksiyetenin kadınlara oranla daha yüksek olduğu gözlemlenmiştir. Sunulan çalışmada ise kızların dental anksiyetesinin erkeklerden fazla olduğu ve istatistiksel olarak anlamlı bir fark bulunduğu saptanmıştır $(p=0.001)$.

Dental korku diş çürüğünün önemli bir göstergesi ve risk faktörüdür 20,28,29. Dental korku ve diş çürüğü, birbirleri için hem sebep hem sonuç olabilir ${ }^{30}$. Kruger ve arkadaşları (31) dental korkunun çürükler için önemli bir belirleyici olduğunu belirtmişlerdir. Yapılan çalışmalarda dental korku ile çürük arasında anlamlı ilişki olduğu görülmüştür ${ }^{31-33}$. Hägglin ve arkadaşları $^{34}$ ve Schuller ve arkadaşları ${ }^{35}$ tarafından yapılan DMFT skorları ve anksiyete ile ilgili çalışmalarda, yüksek anksiyeteye sahip bireylerde çürük diş/ diş yüzeyi ve eksik diş sayısının fazla, restore edilmiş diş sayısının az olduğu rapor edilmiştir. Münevveroğlu ve arkadaşları $^{36}$ yaptıkları çalışmada, DMFT/dmft değerleri ve dental korku arasında güçlü bir ilişki bulmular ve dental korkuya sahip çocuklarda DMFT/dmft değerlerinin yüksek olduğunu bildirmişlerdir. Sunulan çalışmada ise, bu çalışmaların bulgularına benzer şekilde DMFT/dmft değerlerinin yüksek derece anksiyeteli hastalarda fazla olduğu saptanmış ve istatistiksel olarak anlamlı bir fark bulunmuştur $(p=0.030, p=0.015)$. Yüksek anksiyeteli hastalarda çürük sıklığının fazla gözlemlenmesi, çürük ile anksiyete arasında güçlü bir ilişki olduğunu göstermiştir. Ayrıca zaman içerisinde korkuya bağlı olarak tedaviden kaçınma ile ağız sağıılarının daha da kötüleşebileceği ve çürük sayılarının artabileceği düşünülebilir. Bu yüzden dental korkulu hastalarda anksiyetenin azaltılması için alınacak önlemler büyük önem taşır.

Dental anksiyete ve korku, hastada oluşturduğu fizyolojik, düşünsel ve davranışsal farklılıklar sebebiyle gerek ağız sağlığı gerek genel sağlık üzerinde olumsuz etkiler yaratarak bireyin yaşam kalitesini düşürmektedir ${ }^{37}$. Diş hekimliği korkusu ile daha az diş heki mine gitme, kötü ağız bakımı ve ciddi düzeyde fonksi yonel bozukluklar arasında bir ilişki olduğu beli rlenmiştir. Yapılan çalışmalarda anksiyete varlığının diş hekimi ziyaretlerinin sayı ve düzenini değiştirdiği ve anksiyetik hastaların diş hekimi ziyaret sayısını azaltmaya veya ertelemeye yönelik isteklerini bildirdikleri ortaya konulmuştur ${ }^{34,38,39}$. Schuller ve arkadaşlarının 35 yaptıkları bir çalışmada , diş hekimi korku düzeyi yüksek olan bireylerin diş hekimini daha az ziyaret ettikleri ve randevularını daha fazla erteledikleri veya iptal ettikleri rapor edilmiştir. Bu çalışmalarla benzer olarak sunulan çalışmada anksiyeteye sahip hastaların

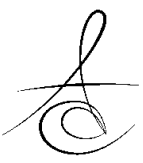


diş tedavisi hizmeti almaktan kaçınmaları sebebiyle, Çocuk Korku Değerlendirme Skalası Dental Alt Ölçeği sonuçlarına göre yüksek dereceli anksiyeteli hasta sayısı az bulunmuştur.

İlk dental ziyaret, önemli bir faktördür ve anksiyetenin ve devam eden ziyaretlerde dental korkunun belirleyicisi olarak görülmektedir ${ }^{40}$. Kırbaş ve

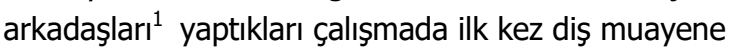
ve tedavisine gelen çocukların, daha önce diş muaye nesi ve tedavisine gelmiş çocuklardan daha anksiyeteli olduğunu saptamışlardır. Folayan ve arkadaşları ${ }^{24}$ ise kliniğe ilk defa gelen 8-13 yaşları arasındaki çocuklarda, tedavi öncesi çocuğun dental anksiyete seviyesi ile yaşı ve cinsiyeti arasında istatistiksel bir ilişki bulamamışlardır. Bu çalışmada ise Kırbaş ve arkadaşlarının ${ }^{1}$ yaptığı çalışmayla benzer olarak daha önce diş hekimine gitmemiş olanların gidenlere göre CFSS-DS anksiyete skoru daha yüksek bulunmuş ve istatistiksel olarak anlamlı bir fark saptanmıştır $(p=0.001)$. Daha önce diş hekimine gitmeyen hastalarda anksiyetenin fazla olmasına, ailedeki bireylerin ve çocuğun arkadaş çevresinin kötü dental tecrübelerini çocuğa aktarması, günümüz teknoloji devrinin sağladığı sosyal medya, televizyon gibi olanaklara çocuğun daha rahat ulaşması ve bunun sonucunda edindiği yanlış bilgiler gibi çevresel faktörler sebep olarak düşünülebilir.

Hekimin cinsiyeti, hastaların anksiyete seviyeleri üzerine etkili olabilmektedir ${ }^{41}$. Daha önce yapıIan çalışmalardaki bulguları destekler şekilde bu çalışmadaki çocukların, aynı cinsiyetteki diş hekimi tarafından tedavi edilmeyi tercih etmesi istatistiksel olarak anlamlı bulunmuştur $(p<0.001)^{42-44}$. Bununla beraber bu bulgunun, yapılan bazı çalış- malardaki bulgularla benzeşmediği görülmüştür ${ }^{45,46}$. Ancak aynı cinsiyete göre çocukların diş hekimi tarafından tedavi edilmesi, dental klinikte tedavi kalitesini artırabilir.

Hekimin görünüşündeki sözlü olmayan iletişim çocuk-hekim ilişkisinde büyük rol oynayabilmektedir ${ }^{41}$. Çocuklar diş hekiminin dış görünüşüne dayanarak erken bir kanı oluşturur ve dental muayene boyunca diş hekiminin her kelimesini, hareketini ve jestlerini kayıt ve analiz ederler ${ }^{47}$. Dunn ve arkadaşları ${ }^{48}$ dış görünüşün bireyin aile doktoru seçmesinde önemli bir faktör olduğunu ve doktor-hasta ilişkisinin gelişmesinde önemli rol oynadığını bulmuşlardır. Bu çalışmanın amaçlarından bir diğeri de, çocukların diş hekimleriyle ilgili güçlü tercihleri ve bakış açıları olduğunu göstermektir. Çocukların hekimin dış görünümüyle ilgili tercihlerini belirlemenin amacı, tercihlere göre hekimin dış görünümünde pozitif değişiklikleri yapmak ve sonucunda çocukların klinikte daha rahat olmasını sağlamak ve dental ziyaretin kalitesini geliştirmektir.

Çalışmadaki çocukların büyük bir çoğunluğu (\%55), diş hekiminin kıyafet tercihleriyle ilgili yapılan diğer çalışmaların ${ }^{41-43}$ sonuçlarıyla uyumlu bir şekilde diş hekiminin geleneksel beyaz önlüğü giymesini tercih etmiştir. Bu bulgu, McCarthy ve arkadaşları ${ }^{49}$ ve Panda ve arkadaşları ${ }^{9}$ tarafından yapılan, yaygın inanışın aksine çocukların beyaz önlüklü doktorlardan korkmadığını ve daha resmi giyinen doktorların daha yetkin ve ilgili olduklarını bulan çalışmaları destekler. Çocuklar, beyaz önlük ile yaşadıkları ülkenin sosyoekonomik şartlarına bağlı olarak, pediatristler ve aile doktorları ya da medya aracılığı ile erkenden tanışırlar. Çocuklar beyaz önlüklü birisini "doktor-diş hekimi" konsepti ile birleştirmiş olabilir. Beyaz önlüğe bu erken alışma, beyaz önlükle ilgili bir ön yargıya sebep olmuş olabilir 50. Çocuklar beyaz önlüğü, iyileşmenin sembolü olarak gördükleri ve geçmiş deneyimlerinden dolayı diş hekiminin beyaz önlük giymesini beklemeye şartlandıkları için tercih edebilirler ${ }^{12,42}$.

Münevveroğlu ve arkadaşlarının ${ }^{36}$ yaptığı çalışmada çocukların \%76'sının beyaz önlük yerine renkli önlükleri tercih etmesi bulgusunu destekler şekilde, sunulan çalışmada da renkli önlükler \%44 oranında tercih edilmiştir. Ayrıca Kuşçu ve arkadaşlarının 50 çocuk dostu kıyafet konseptinin endişeli çocuklarda ilk iletişimi güçlendirir bulgusunu destekler şekilde, sunulan çalışmada renkli önlüğü tercih eden hastaların CFSS-DS anksiyete skoru beyaz önlüğü tercih edenlere göre yüksek bulunmuştur. Buna göre hekimler, anksiyetesi yüksek hastalarda pedodontik önlük konseptinin çocukların rahatlamasını ve dolayısıyla anksiyetenin azalmasını sağlayabileceğini göz önünde bulundurmalıdır.

Diş hekimliği mesleğinde, hasta ve hekim arasında enfeksiyonun bulaşımı ile ilgili yüksek risk vardır. Bu yüzden eldiven, yüz maskesi, gözlük ve bone gibi koruyucu ekipmanların kullanımı oldukça önerilmektedir ${ }^{9}$. Panda ve arkadaşlarının ${ }^{9}$ yaptığı çalışmada, çoğu çocuk diş hekiminin gözlük ya da bone kullanmasını tercih etmemiştir. AlSarheed'in 42 yaptığı çalışmada ise, çocukların sadece \%40'ı koruyucu ekipman kullanımını tercih etmiştir. Ancak McKenna ve arkadaşlarının 51 yaptığı çalışmada, katılımcıların büyük çoğunluğu (\%56) diş hekiminin

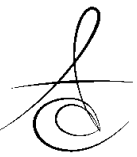


koruyucu gözlük kullanmasını tercih etmiştir. Çocuklar ve ebeveynleri üzerinde yapılan bir başka çalışmada, çocukların \%66'sı ve ebeveynlerin \%71'i diş hekimlerinin koruyucu ekipman kullanmasını tercih etmiştir 43. Shulman ve Brehm'in ${ }^{52}$ yaptığı çalışmada ise, çocukların \%70'inin diş hekiminin koruyucu ekipman kullanımını tercih ettiği görülmüştür. Münevveroğlu ve arkadaşlarının ${ }^{36}$ yaptığı çalışmada ise, Shulman ve Brehm'in ${ }^{52}$ çalışmasındaki bulgulara çok benzer olarak hastaların \%70.5'i diş hekiminin maske kullanmasını tercih etmiştir. Mistry ve arkadaşlarının ${ }^{41}$ yaptığı çalışmada ise, koruyucu gözlük kullanımının daha az tercih edildiği, sebebinin ise çocuklarla göz kontağının kısıtlanması olarak bildirilmiştir. Bu çalışmada ise benzer olarak çocukların \%44'ünün maske kullanımını, $\% 42$ 'sinin maske ve koruyucu gözlük kullanımını tercih ettiği görülmüştür. Çocuklar bu ekipmanlardan korkabilir ve koruyucu amaçlarından haberdar olmayabilirler. $\mathrm{Bu}$ korku, koruyucu ekipmanların amaçları anlatılarak sakinleştirilebilir.

Bu çalışmada, çocuklardan diş hekiminin kullanmasını tercih ettikleri eldivenin rengini seçmeleri istendiğinde, Panda ve arkadaşlarının ${ }^{9}$ yaptığı çalışmayı destekler şekilde çocukların büyük çoğunluğunun (\%51) beyaz eldiveni tercih ettiği görülmüştür. Bunun sebebi, geçmişte kendi diş hekimlerinin sadece beyaz eldiven kullandıklarını deneyimlemeleri ve rengin aşinalığı sebebiyle akıllarının beyaza şartlanması olabilir.

Ayrıca bu çalışmadaki çocukların büyük bir çoğunluğu Panda ve arkadaşlarının yaptığı ${ }^{9}$ çalışmayı destekler şekilde diş hekimlerinin çizgi film karakterli maske yerine düz, beyaz maske takmalarını tercih etmiştir. Bunun sebebi de düz maskenin aşinalığı olabilir. Özellikle büyük yaş gruplarının daha önce diş hekimini ziyaret etmiş olmaları daha olasıdır. Daha küçük yaş grupları büyüklerle karşılaştırıldığında, büyük intimalle onları büyülediği ve dental ziyaret kaynaklı endişeyi azalttığı için çizgi film karakterleri çizilmiş pedodontik maske fikrini daha kolay kabul edebilir.

Literatür taramasında AlSarheed ${ }^{42}$, McCarthy ve arkadaşları ${ }^{49}$ ve Münevveroğlu ve arkadaşları ${ }^{36}$ tarafından yapılan çalışmalarda, hastaların çoğu oyuncaklar ve posterlerle dizayn edilmiş dekore kliniği tercih etmişlerdir. Ancak sunulan çalışmada çocukların $\% 57$ 'si düz, sade bir klinikte tedavi olmayı tercih etmişlerdir. Bu farkıı̆ın sebebi olarak çocukların önceki diş kliniği deneyimleri gösterilebilir. Dekore kliniği tercih eden hasta grubunun ise CFSS-DS anksiyete skoru daha yüksek bulunmuştur. Buna göre anksiyeteli hasta grubunda dental klinik ortamında bulunan oyuncak ve posterler dikkat dağıtıcı unsur olarak işlev görebilir ve çocuğun dental tedaviyi daha kolay kabullenebilmesini sağlayabilir.

Dental korkulu çocuklar diş hekimleriyle tanı, davranış yönlendirmesi ve tedavi seçenekleri konusunda mücadele içine girmektedirler. Özellikle çocuk hastalarla uğraşan diş hekimleri tedaviye başlamadan önce çocukla dostça ilişki kurmaya çalışmalıdırlar. Pozitif bir hekim -hasta ilişkisinin ; çocuk hastanın uyumunu, diş hekimine gitme alışkanlığını ve hekimin evde yapacağı koruyucu uygulamalar açısından motivasyonu sağlayacağı gözardı edilmemelidir . Diş hekimi çocuktaki dental korkunun azalarak tedaviye karşı daha iyimser bir tutum geliştirmesine ve iyi bir ağız diş sağlığı kazanmasına yardımcı olmalıdır. Ayrıca hekimin görünüşü üzerinde küçük değişiklikler yapmak çocuğun kendini daha rahat hissetmesini ve endişe seviyesinin azalmasını sağlayabilir. Böylece çocuğun tedaviyi kabul etme şansı artmış olur. Fakat bütün bu görüşler ile ilgili kesin yargılara varabilmek için daha geniş çaplı çalışmalara intiyaç duyulmaktadır.

Özge Yahyaoğlu: ORCID ID: 0000-0003-2220-7654

Özgül Baygın: ORCID ID: 0000-0003-0836-7619

Görkem Yahyaoğlu: ORCID ID: 0000-0003-2220-7655

Tamer Tüzüner: ORCID ID: 0000-0001-5817-5928

\section{KAYNAKLAR}

1. Kırbaş ZO , Özkan H . Ağız diş sağlığı merkezine başvuran 9-12 yaş grubu çocukların durumluk kaygı düzeylerinin belirlenmesi . Behçet Uz Çocuk Hast Derg 2014; 4: 128-34.

2. Akarslan $\mathrm{Z}$, Erten $\mathrm{H}$. Diş hekimliği korkusu ve kaygısı. Hacettepe Diş Hek Fak Derg 2009; 1:62-8.

3. Özdaş Öner D, Zorlu S. Diş kliniğinde "kim, neden, niye korkar?". Turkiye Klinikleri J Pediatr DentSpecial Topics 2015; 1: 18-23.

4. Bayrak S, Şen ET, Eğilmez T, Tüloğlu N. Ebeveyn dental kaygısı ve sosyodemografik faktörlerin çocukların dental kaygısı üzerine etkileri . Atatürk Üniv Diş Hek Fak Derg 2010; 20: 181-8.

5. Bodrumlu $E$, Sümer $A P$, Sümer $M$, Köprülü $H$. Ondokuz Mayıs Üniversitesi Dişhekimliği Fakültesine başvuran bireylerde dental korkunun değerlendirilmesi. Hacettepe Diş Hek Fak Derg 2006; 30: 51-6. 
6. Locker D, Poulton R, Thomson WM. Psychological disorders and dental anxiety in a young adult population. Commun Dent Oral Epidemiol 2001; 29: 456-63.

7. Peretz B, Mann J. Dental Anxiety Among Israeli Dental Students: a 4-year longitudinal study. Eur J Dent Educ 2000; 4: 133-7.

8. Kent GG. The Psychology of Dental Care. 2nd ed. Bristol: Wright; 1991; 43-65.

9. Panda A, Garg I, Bhobe AP. Children's perspective on the dentist's attire. Int J Paediatr Dent 2014; 24: 98-103.

10. Kleinknecht RA, Klepac RK, Alexander LD. Origins and characteristics of fear of dentistry. J Am Dent Assoc 1973; 86: 842-6.

11. Mathewson RJ, Primosch RE. Behavioral and Physical Assesment. Fundamentals of Pediatric Dentistry Carol Stream. 2nd ed. IL: Mosby; 1995; 7-23.

12. Panda A, Garg I, Shah M. Children's pereferences concerning ambiance of dental waiting rooms. Eur Arch Paediatr Dent 2015; 16: 27-33.

13. Cuthbert MI, Malamed BG. A screening device: children at risk for dental fear and management problems. ASDC J Dent Child 1982; 49: 432-6.

14. Köroğlu A, Durkan R. Diş hekimliği uygulamalarında karşılaşılan dental anksiyete sendromunun etiyolojisinin ve tedavi yöntemlerinin değerlendirilmesi. Atatürk Üniv Diş Hek Fak Derg 2010; 20: 205-12.

15. Akbay Oba A ， Dülgergil CT , Saroğlu Sönmez I . Prevalence of dental anxiety in 7- to 11-year-old children and its relationship to dental caries. Med Princ Pract 2009; 18: 453-7.

16. Ergüven SS, Işık B, Kılınç Y. Diş hekimliği fakültesi birinci sınıf öğrencileri ile son sınıf öğrencilerinin dental kaygı -korku düzeylerinin karşılaştırmalı olarak değerlendirilmesi . Acta Odontol Turc 2013; 30: 70-6.

17. Önçağ $O$ ， Çoğulu D . Ailenin sosyoekonomik durumu ve eğitim düzeyinin çocuklarda dental kaygı üzerine etkisi . A.Ü. Diş Hek Fak Derg 2005; 32: 45-54.

18. Lee CY, Chang YY, Huang ST. Prevalence of Dental Anxiety among 5-to8-Year-Old Taiwanese Children. Am Assoc Pub Health Dent 2007; 67: 36-41.

19. Wogelius P, Poulsen S, Sørensen T. Prevalence of dental anxiety and behaviour management problems among six to eight years old Danish children. Acta Odontol Scand 2003; 61: 178-83.

20. Klingberg G. Reliability and validity of the Swedish version of the Dental Subscale of the Children's Fear Survey Schedule, CFSS-DS. Acta Odontol Scand 1994; 52: 255-6.

21. Raj S, Agarwai M, Aradhya K, Konde S, Nagakisore V. Evaluation of Dental Fear in Children during Dental Visit using Children's Fear Survey ScheduleDental Subscale. Int J Clin Pediatr Dent 2013; 2013: 12-5.

22. Majstorovic M, Veerkamp JS, Skrinjaric I Reliability and validity of measures used in assessing dental anxiety in 5- to 15-year-old Croatian children. Eur J Paediatr Dent 2003; 4: 197-202.

23. Yamada MKM, Tanabe $Y$, Sano $T$, Noda $T$. Cooperation during dental treatment: the Children's Fear Survey Schedule in Japanese children. Int J Ped Dent 2002; 12: 404-9.

24. Folayan MO, Idehen EE, Ufomata $D$. The effect of sociodemographic factors on dental anxiety in children seen in a suburban Nigerian hospital. Int J Paediatr Dent 2003; 13: 20-6.

25. Le Baron S, Zeltzer L. Assessment of acute pain and anxi- ety in children and adolescents by selfreports, observer reports and a behavior checklist. J Consult Clin Psychol 1984; 52: 729-38.

26. Corah NL. Development of a dental anxiety scale. J Dent Res 1969; 48: 596.

27. Stabholz A, Peretz B. Dental Anxiety Among Patients Prior To Different Dental Treatments. Int Dent J 1999; 49: 90-4.

28. Liddell A, Murray P. Sex and age differences in children's reports of dental anxiety and selfefficacy relating to dental visits. Canad J Behav 1989; 21: 270-8.

29. Milgrom $P$, Mance IL, King B, Weinstein P. Origins of childhood dental fear. Behav Res Ther 1995; 33: 313-9.

30.ten Berge M, Veerkamp JS, Hoogstraten J, Prins PJ. Childhood dental fear in the Netherlands: prevalence and normative data. Community Dent Oral Epidemiol 2002; 30: 101-7.

31. Kruger E, Thomson WM, Poulton R, Davies S, Brown RH, Silva PA. Dental caries and changes in dental anxiety in late adolescence. Community Dent Oral Epidemiol 1998; 26: 355-9.

32. Rantavuori K, Lahti S, Hausen H, Seppa L,

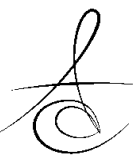


Karkkainen S. Dental fear and oral health and family characteristics of Finnish children. Acta Odontol Scand 2004; 62: 207-13.

33. Alvesalo I, Murtomaa P, Milgrom $P$, Honkanen A, Karja-lainen M, Tay KM. The Dental Fear Survey Schedule: a study with Finnish children. Int J Paed Dent 1993; 3: 193-8.

34. Hägglin C, Hakeberg $M$, Ahlqwist $M$, Sullivan $M$, Berggren $U$. Factors associated with dental anxiety and attendance in middle-aged and elderly women. Community Dent Oral Epidemiol 2000; 28: 451-60.

35. Schuller AA, Willumsen $T$, Holst D. Are there differences in oral health and oral health behavior between individuals with high and low dental fear? Community Dent Oral Epidemiol 2003; 31: 116-21.

36. Münevveroğlu AP, Akgöl BB, Erol T. Assessment of the feelings and attitudes of children towards their dentist and their association with oral health. doi: http://dx.doi.org/10.1155/2014/867234. Hindawi Publishing Corporation Dentistry 2014; 4 pages.

37. Ay ZY, Çağlar F, Orun B, Uskun E. Hastaların ağız sağlığı, dental anksiyete düzeyleri ve olası belirleyicileri ile ilgili bildirimlerinin ölçek sonuçlarıyla tutarılıı̆ı. SDÜ Sağ Bil Derg 2014; 5: 56-61.

38. Doerr PA, Lang WP, Nyquist LV, Ronis DL. Factors associated with dental anxiety. J Am Dent Assoc 1998; 129: 1111-9.

39. Abrahamsson KH, Berggren U, Carlsson SG. Psychosocial aspects of dental and general fears in dental phobic patients. Acta Odontol Scand 2000; 58: 37-43.

40. Nicolas E, Bessadet M, Collado V, Carrasco P, Rogerleroi V, Hennequin $M$. Factors affecting dental fear in French children aged $5-12$ years. Int J Paediatr Dent 2010; 20: 366-73.

41. Mistry D, Tahmassebi JF. Children's and parents' attitudes towards dentists' attire. Eur Arch Paediatr Dent 2009; 10: 237-40.

42. AlSarheed M. Children's Perception of their dentists. Eur J Dent 2011; 5: 186-90.

43. Ellore VPK, Mohammed M, Taranath M, Ramagoni NK, Kumar V, Gunjalli G. Children and Parent's Attitude and Preferences of Dentist's Attire in Pediatric Dental Practice. Int J Clin Pediatr Dent 2015; 8: 102-7.

44. Tong HJ, Khong J, Ong C, Ng B, Lin Y, Ng JJ, et al.
Children's and parents' attitudes towards dentists' appearance, child dental experience and their relationship with dental anxiety. Eur Arch Paediatr Dent 2014; 15: 377-84.

45. Keenum AJ, Wallace LS, Stevens AR. Patients' attitudes regarding physical characteristics of family practice physicians. South Med J 2003; 96: 1190-4.

46. Rehman SU, Nietert PJ, Cope DW, Kilpatrick AO. What to wear today? Effect of doctor's attire on the trust and confidence of patients. Am J Med 2005; 118: 279-86.

47. Kleinknecht RA, Klepac RK, Alexander LD. Origins and characteristics of fear of dentistry. J Am Dent Assoc 1973; 86: 842-6.

48. Dunn JJ, Lee TH, Percelay JM, Fitz JG, Goldman L Patient and officer attitudes on physician attire and etiquette. JAMA 1987; 257: 65-8.

49. McCarthy JJ, McCarthy MC, Eilert RE. Children's and parents' visual perception of physicians. Clin Pediatr 1999; 38: 145-52.

50. Kuscu OO, Caglar E, Kayabasoglu N, Sandalli N. Preferences of dentist's attire in an group of Istanbul school children related with dental anxiety. Eur Arch Paediatr Dent 2009; 10: 38-41.

51. McKenna G, Lillywhite GRR, Maini N. Patient preferences for dental attire: a cross-sectional survey in a dental hospital. Brit Dent J 2007; 203: 681-5.

52. Shulman ER, Brehm WT. Dental clinical attire and infection-control procedures: Patients' attitudes. J Am Dent Assoc 2001; 132: 508-16.
Yazışma Adresi
Doç. Dr. Özgül BAYGIN
Karadeniz Teknik Üniversitesi
Diş Hekimliği Fakültesi Pedodonti Anabilim Dalı, 61080,Trabzon / Türkiye
TIf: 05327607660
e-posta: dtozgul@gmail.com 